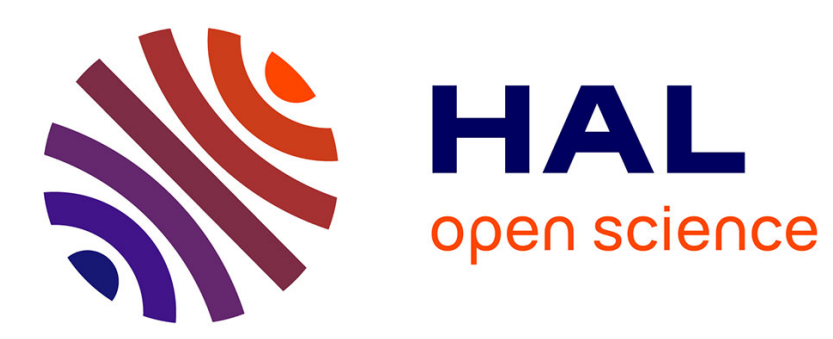

\title{
Interbank Deposits and Market Discipline: Evidence from Central and Eastern Europe
}

Isabelle Distinguin, Tchudjane Kouassi, Amine Tarazi

\section{To cite this version:}

Isabelle Distinguin, Tchudjane Kouassi, Amine Tarazi. Interbank Deposits and Market Discipline: Evidence from Central and Eastern Europe. Journal of Comparative Economics, 2013, 41 (2), pp.544560. 10.2139/ssrn.2119956 . hal-01098716

\section{HAL Id: hal-01098716 https://hal.science/hal-01098716}

Submitted on 28 Dec 2014

HAL is a multi-disciplinary open access archive for the deposit and dissemination of scientific research documents, whether they are published or not. The documents may come from teaching and research institutions in France or abroad, or from public or private research centers.
L'archive ouverte pluridisciplinaire HAL, est destinée au dépôt et à la diffusion de documents scientifiques de niveau recherche, publiés ou non, émanant des établissements d'enseignement et de recherche français ou étrangers, des laboratoires publics ou privés. 
Interbank Deposits and Market Discipline: Evidence from Central and Eastern Europe

\author{
Isabelle Distinguin $^{\mathrm{a}}$, Tchudjane Kouassi ${ }^{\mathrm{a}, *}$, Amine Tarazi $^{\mathrm{a}}$ \\ ${ }^{a}$ Université de Limoges, LAPE, 5 rue Félix Eboué BP 312787031 Limoges, France
}

\begin{abstract}
There is a considerable debate on the role played by market discipline in the banking industry. Using data for 207 banks across 10 Central and Eastern European countries, this paper empirically analyzes the disciplining role of interbank deposits. We find that market discipline has been effective in Central and Eastern Europe since the implementation of explicit deposit insurance. However, several factors affect the strength of this discipline. State-owned banks are not disciplined probably because they benefit from implicit insurance. Institutional and legal factors, and resolution strategies adopted by countries during banking crises also impact bank risk and the effectiveness of market discipline. Our results indicate that stronger regulatory discipline reduces risk but also weakens market discipline.
\end{abstract}

Keywords: bank risk, market discipline, interbank deposits, transition economics

JEL Classifications: G21, G28

\footnotetext{
$\hat{W}$

We are very grateful to two anonymous reviewers, Paul Wachtel, Iftekhar Hasan, Joel Petey, Philippe Rous and delegates at the 27th Symposium on Money, Banking and Finance (GDRE), Bordeaux, 2010, 45th Annual Conference, Canadian Economic Association, Ottawa, 2011, 60 $0^{\text {th }}$ Annual Conference of the French Economic Association (AFSE), Paris, 2011, Annual Meeting of The Financial Management Association (FMA), Denver, 2011 and Spring Conference of the French Finance Association (AFFI), , Strasbourg, 2012 for constructive comments on earlier versions of the paper. All errors, of course, rest with the authors.

* Corresponding author. Tel.: +33 555149 251; Fax: +33 555149206

E-mail addresses: isabelle.distinguin@unilim.fr (I.Distinguin), tchudjane.kouassi@unilim.fr (T.Kouassi),

amine.tarazi@unilim.fr (A. Tarazi).
} 


\section{Introduction}

Economists and bank regulators have shown a growing interest in favoring the reliance on market forces and higher involvement of private agents such as uninsured creditors to monitor banks (Flannery (2001), BIS (2003)). Concomitantly, the Basel Committee on Banking Supervision has designated market discipline the third of the three pillars of the regulatory framework. Market forces are assumed to reinforce bank capital regulation and supervision to ensure the safety of the banking system. However, for market discipline to be effective, several conditions must be fulfilled: market agents must feel at risk and must have sufficient information about the actual riskiness of banks (Hamalainen et al. (2005), Nier and Baumann (2006)). Thus, explicit deposit insurance with a coverage limit might serve as a signal that eliminates the unlimited coverage of the de facto implicit deposit insurance system. ${ }^{1}$ However, even in presence of explicit insurance other factors are likely to affect the incentives of uninsured creditors to monitor banks. Some banks can still benefit from implicit government insurance. For example, state-owned banks might be considered by uninsured creditors as implicitly insured which should remove their incentives to monitor them (Borisova and Megginson (2012)). Similarly, some country specificities might affect the effectiveness of market discipline. Angkinand and Wihlborg (2010) show for example that market discipline depends on the extent of explicit deposit insurance, as well as on the credibility of non-insurance of creditors. Banks face a combination of regulatory discipline and market discipline. Market discipline implies that the cost and availability of debt depend on bank risk. Regulatory discipline is based on risk-weighted capital requirements, insurance premiums and examination frequency and intensity (Billet et al. (1998)). Thus, the incentives of uninsured creditors to monitor banks might also depend on the strength of regulatory discipline: stronger regulatory discipline might weaken market discipline.

The aim of this paper is to assess the effectiveness of market discipline and the factors affecting its strength in the Central and Eastern European context. While most of the previous studies focus on Europe or on the U.S. where financial markets are well developed and where

\footnotetext{
${ }^{1}$ Explicit or formal deposit insurance is different than implicit deposit insurance. Explicit deposit insurance is based on formal regulation through central bank law, banking law, or the constitution. These laws define for example the coverage limits and the funding mode of the deposit insurance system, and how bank failures will be resolved. In absence of explicit deposit insurance, the deposit insurance is implicit that is depositors are protected by the bank monitoring and regulatory authority which does so without specifying guarantees regarding the extent of the protection (Demirgüc-Kunt et al. (2005)). Most countries have henceforth explicit insurance schemes.
} 
the potential instruments of market discipline are broad, we consider Central and Eastern European countries where the conditions of the effectiveness of market discipline may be doubtful and where the potential instruments of market discipline are almost inexistent. ${ }^{2}$ In fact, it is well-known that market discipline is likely to contribute to financial stability, but evidence from cross-country studies show that market discipline is possible only if it is promoted by rigorous accounting and auditing rules and in absence of generous deposit insurance schemes (Barth et al. (2004)). In other words, low-income countries would lack the prerequisites for market discipline and regulators would have to rely only on capital adequacy rules and bank supervision, the two first Basel II pillars.

Besides, Central and Eastern European countries have implemented explicit deposit insurance in the 1990's. Indeed, within the framework of the liberalization of their banking market, starting in the early 1990's, they have implemented explicit deposit insurance systems to comply with the European Union (EU) Directive on Deposit Insurance and to deal with the banking distress that they suffered at the beginning of their transition process. The existence of an implicit insurance beforehand, that covered most creditors (large and small), had presumably undermined market discipline. The implementation of explicit deposit insurance should have created the conditions for effective market discipline.

In this paper, using bank-level and country-level data under explicit deposit insurance from 1995 to 2006 for 10 countries, we examine the effectiveness of market discipline by focusing on deposits and more specifically interbank deposits which are explicitly uninsured. We question whether banks that are more reliant on interbank deposits take less risk. We also investigate how some aspects of regulatory discipline and some bank specificities affect the effectiveness of market discipline by influencing the incentives of uninsured creditors to monitor banks. Specifically, we investigate the following empirical questions. First, we test the effectiveness of market discipline on government controlled banks assuming that these banks are less prone to market discipline. Indeed, state-owned banks might benefit from an implicit insurance from the government. Second, we examine whether higher deposit insurer power weakens the impact of interbank deposit on bank risk-taking. We assume that the disciplinary role of interbank deposits weakens as regulatory discipline is stronger. Third, we analyze the impact of the previous banking crises resolution strategies on the effectiveness of

\footnotetext{
${ }^{2}$ Indeed, there are only few listed banks which limits the use of indicators based on equity markets. Similarly, subordinated debt which is an instrument frequently used in the literature on market discipline (Sironi (2003), Morgan and Stiroh (2001)) cannot be used for these countries because of illiquidity issues: very few banks issue subordinated debt and only for small amounts.
} 
market discipline. We assume that the effectiveness of market discipline is higher in countries that have pursued liquidation strategies rather than recapitalizations.

The key findings are as follows. First, we find that under explicit deposit insurance (which has been implemented in the 1990's), interbank deposits do play a disciplining role in Central and Eastern Europe. However, we also find that several factors affect the effectiveness of market forces. Interbank deposits do not moderate the risk behavior of stateowned banks presumably because of an implicit and unlimited insurance perceived for such banks by market participants. The effectiveness of market discipline is also affected by the regulatory environment and notably the resolution strategies adopted by each country during banking crises and the power of the deposit insurer. Our results indicate that when regulatory discipline is strong, market discipline is undermined.

The remainder of this paper is organized as follows. Section 2 reviews the literature and explains how this work extends the existing literature. Section 3 presents our sample, variables and method. The empirical results are presented in section 4. Section 5 is dedicated to robustness checks. Section 6 concludes.

\section{Related literature and research focus}

Many empirical studies have addressed the issue of the existence and the effectiveness of market discipline. Several types of agents can discipline banks. Some papers focus on the discipline exerted by depositors. For example, Martinez-Peria and Schmukler (2001) show, using a sample of banks from Argentina, Chile and Mexico, that depositors withdraw their deposits from bad banks or require higher interest rates on their deposits, suggesting the presence of market discipline, even among small-insured depositors. Boot and Greenbaum (1993) establish theoretically that, when banks raise funds, the cost of funds is related to the bank's risk profile. Banks face lower costs when they invest in safe assets than when they invest in risky assets. A broad literature focuses on subordinated debt holders showing that the spreads on subordinated debt reflect bank riskiness (Flannery and Sorescu (1996), Jagtiani et al. (1999)). Other papers show that indicators based on equity prices can reflect bank riskiness (Curry et al. (2008), Gropp et al. (2006)). The conditions of effectiveness of market discipline are also studied by some authors showing notably that, for market discipline to be 
effective, market agents must feel at risk and must have sufficient information about bank riskiness (Hamalainen et al. (2005), Nier and Baumann (2006)).

Our paper is more specifically related to a strand of the literature on market discipline focusing on interbank deposits. Indeed, making banks themselves the monitors of others banks, assuming that similar institutions might be expected to better identify a peer's risk, has been often encouraged in the literature. Under such an approach interbank deposits form the ideal tool to ensure the effectiveness of market discipline. Such deposits are not covered by explicit deposit insurance schemes. Besides, banks are likely to be informed investors on the interbank market. As the lending bank may be directly affected by a sudden change in the health and soundness of the borrowing bank, interbank deposits should be sensitive to the risk taken by the borrowing bank. Rochet and Tirole (1996) indicate that as banks are particularly good at identifying the risks of other banks and have incentives to monitor other banks in an interbank borrowing relationship; the extent of interbank exposures may contribute to restrain bank excessive risk taking and reduce the risk of bank failures. Thus, interbank deposits can generate market discipline and perform a complementary task to bank regulation and supervision by public authorities.

However, the empirical literature on the ability of banks to identify the risk of other banks is scarce. One of the first papers using interbank deposits as factors of market discipline is that of Furfine (2001), which analyzes the pricing of interbank lending agreements. The author investigates the risk pricing on the fed-funds market and finds that borrowing banks with higher profitability, higher capital ratios, and fewer problem loans pay lower interest rates than others when they borrow overnight. King (2008) also finds, using data on the U.S. interbank market between 1986 and 2005, that the rate a bank pays for interbank loans depends to some extent on its riskiness, particularly its credit risk, and the reliance on these funds tends to decrease as their cost rises.

Other papers suggest that interbank deposits can be considered as a market discipline factor that contributes to limit bank risk-taking. Nier and Baumann (2006) test whether factors associated with the strength of market discipline, specifically the proportion of deposits received from other banks, lead banks to choose higher capital buffers for a given level of asset risk. Considering individual listed banks from 32 different countries over the years 1993 to 2000 , they find that banks holding a higher proportion of interbank deposits have greater incentives to limit their insolvency risk by choosing a larger capital buffer. Dinger and Von Hagen (2009) also show, considering a sample of banks from Central and Eastern Europe 
(CEE), that interbank borrowing is associated with lower risk taking of borrowing banks. Cocco et al. (2009) examine the importance of relationships, measured by the intensity of pair-wise lending activity, in the process of liquidity provision on the interbank market. Using data on the Portuguese interbank market between January 1997 and August 2001, they find that relationships are an important determinant of banks' ability to access interbank market liquidity. Banks with a larger imbalance in their reserve deposits are more likely to borrow funds from banks with which they have a relationship, and to pay a lower interest rate on these loans. Besides, they find that small banks and banks with a higher proportion of nonperforming loans tend to rely more on relationships when borrowing funds on the interbank market.

This paper extends earlier works in several directions. First, while most of the existing literature focuses on developed countries, we consider Central and Eastern European countries which have less developed banking industries and financial markets. These countries have introduced explicit deposit insurance systems relatively later than other countries, in the 1990's. Investigating market discipline is of particular interest in the case of these countries because the conditions of its effectiveness appear less favorable than in other countries. Moreover, because market discipline is expected to be weaker in such a context because of less developed financial markets it is important to determine what factors could improve its strength and reliability. Second, we focus on the discipline within the interbank market by looking at interbank deposits. Because stock markets and bond markets are relatively narrow and less liquid than in western countries, we do not deal with the role played by subordinated debt holders which has been the main concern of numerous U.S. studies. We consider that banks are likely to be informed investors and therefore risk-sensitive lenders because their (interbank) deposits are not insured. Third, we explicitly focus on the effectiveness of market discipline in the presence of explicit deposit insurance schemes. Indeed, the introduction of explicit insurance is beneficial for market discipline in countries where implicit insurance was broad in the absence of explicit insurance. Explicit deposit insurance is expected to create the conditions for the effectiveness of market discipline by credibly excluding some creditors from the perspective of a bail out in the event of bank default and interbank deposits are explicitly excluded from the deposit insurance scheme. Fourth, we investigate how some aspects of banking supervision and bank specificities might affect market discipline. For example, state-owned banks might benefit from an implicit insurance from the government. In this case, market discipline could be weaker for such 
banks. Thus, we take into account several features likely to impact the effectiveness of market discipline: the power of the deposit insurer, the existence of an implicit insurance through state guarantee and the resolution strategies adopted in each country during the banking crises they experienced to assess the credibility of imposing losses to uninsured creditors in case of bank failures.

\section{Sample, variables and method}

Before presenting our set of variables and the method, we provide information about our sample of banks and the collected data.

\subsection{Sample}

Our sample consists of commercial banks established in 10 Central and Eastern European transition countries: Bulgaria, Czech Republic, Estonia, Hungary, Latvia, Lithuania, Poland, Romania, Slovakia and Slovenia. ${ }^{3}$ Accounting data (annual financial statements) for individual banks are obtained from Bankscope Fitch IBCA. The sample period is from 1995 to 2006. However, since our focus is on the disciplinary role of interbank deposits and because a necessary condition for market discipline to be effective is that creditors are credibly excluded from any guarantee, we restrict our analysis to the period covering the presence of an explicit deposit insurance scheme. Our argument is that the disciplinary effect of interbank deposits will be effective only when such liabilities are explicitly excluded from any formal guarantee i.e. after the introduction of explicit deposit insurance. Thus, the actual starting date for each country in our sample is the date of introduction of explicit deposit insurance. ${ }^{4}$

\footnotetext{
${ }^{3} 26$ banks in Bulgaria, 27 in Czech Republic, 6 in Estonia, 24 in Hungary, 21 in Latvia, 9 in Lithuania, 40 in Poland, 18 in Romania, 19 in Slovakia, and 17 in Slovenia.

${ }^{4}$ This date is 1993 for Hungary, 1994 for the Czech Republic, 1995 for Poland, 1996 for Bulgaria, Lithuania, Romania, and Slovakia, 1998 for Estonia and Latvia, and 2001 for Slovenia.
} 
Bankscope reported for the period under study balance sheets and income statements for 324 commercial banks for the countries we consider in this study. We delete 117 banks with less than 4 consecutive years of time series observations. This restriction allows us to compute our dependent variables using 4-year rolling windows. Our final sample consists of 207 banks. Table 1 shows some descriptive statistics for the raw sample of 324 banks and the final sample of banks we use. The univariate statistics of these two samples are very similar. Besides, on average as of 2006 , the final sample of banks constitutes over $89.23 \%$ of the total commercial banks' assets of the different sample countries (the lowest is $65.35 \%$ for Poland and the highest is $98.55 \%$ for Bulgaria). ${ }^{5}$ By considering some key accounting ratios on our final sample, we notice that deposits account for a large share of total liabilities. On average, banks receive $76.16 \%$ of deposits relatively to total assets. On the asset side, the average value of the net loans to total assets ratio is equal to $44.59 \%$. Considering profitability, the average ROA equals $0.98 \%$. In terms of capitalization, the average equity to total assets ratio amounts to $13.18 \%$.

\section{< Insert Table 1 >}

\subsection{Presentation of variables}

We present our dependent variables reflecting bank risk and the different independent variables introduced in our estimations. Descriptive statistics regarding these variables are given in Table 2.

\section{< Insert Table 2 >}

\subsubsection{Bank risk measures}

We consider several variables reflecting bank risk which are all computed on the basis of 3-year rolling windows but also 4-year rolling windows for robustness considerations. We take the Z-SCORE as a measure of individual bank default risk. The Z-SCORE is defined as:

\footnotetext{
${ }^{5}$ For the other countries the percentages are as follows (in 2006): 90.24\% for Czech Republic, 98.06 for Estonia, $80.59 \%$ for Hungary, $98.12 \%$ for Latvia, $98.82 \%$ for Lithuania, $80.69 \%$ for Romania, $88.86 \%$ for Slovakia and $93.06 \%$ for Slovenia.
} 
where $R O A$ is the 3-year rolling window average return on assets defined as the ratio of net income to average total assets, EQTA represents the average ratio of equity to total assets and SDROA stands for the 3-year rolling window standard deviation of the return on assets. All the ratios are in percentages. The Z-SCORE has been widely used in the literature as a measure of bank default risk (see Roy (1952), Hannan and Hanweck (1988), Boyd et al. (1993) and De Nicolo (2000)). A lower Z-SCORE value indicates a higher probability of bank failure.

As measures of banks' assets risk, we use the 3-year rolling window standard deviation of the return on assets $(S D R O A)$ and the 3-year rolling window of the standard deviation of the return on equity (SDROE). A higher standard deviation indicates higher risk taking.

\subsubsection{Market discipline factor}

To examine empirically the hypothesis that market discipline is effective in providing incentives for banks to limit their risk, we need an indicator of market discipline. We follow Nier and Baumann (2006) and consider a measure of market discipline based on uninsured liabilities. This variable is the share of deposits received from other banks in total deposits $(M K D)$. By nature, interbank deposits are not covered by explicit deposit insurance schemes, and this is the case in all the countries of our sample. Besides, banks are likely to be informed investors in the interbank market. A lending bank may be subject to the same risk as the borrowing bank. Consequently, interbank deposits are likely to be sensitive to the risk the borrowing bank is taking. The share of subordinated debt in total liabilities is an alternative variable used in several studies, including that of Gropp et al. (2006) and Sironi (2003), showing that subordinated debt spreads reflect the risk profile of the bank. Thus, subordinated debt holders are apparently able to correctly assess bank risk. However, note that, in our sample, there are at least 50 percent of banks which did not issue subordinated debt, and among banks which issued subordinated debt during the period under study, most of them provide information only for one or two years on our sample period. For this reason, we solely focus on interbank deposits. Table 2 shows that the average value of the ratio of banks deposits to total deposits is equal to $28.57 \%$ with a great deal of heterogeneity across banks 
as shown by the standard deviation (26.47) and by the extreme values of this ratio (the lowest value is equal to $0 \%$ and the highest to $100 \%$ ).

\subsubsection{Control Variables}

In our empirical analysis, we include a set a control variables known to affect the riskiness of individual banks. These variables capture individual bank characteristics and reflect macroeconomic factors, the institutional environment and the regulatory and supervisory process at the country level.

\subsubsection{Bank characteristics}

We consider several control variables at the bank level. We include the natural logarithm of total assets (LTA) as a proxy of bank size. The nature of the relationship with bank risk is ambiguous. Indeed, larger banks are assumed to have a greater ability to diversify their risk and thus should have more stable earnings reducing their insolvency risk. However, in the presence of a too-big-to-fail (TBTF) policy, larger banks might have incentives to take higher risk, as indicated by Galloway et al. (1997), and Beck and Laeven (2006). We also control for bank capitalization defined as the ratio of equity to total assets $(E Q T A) .{ }^{6}$ We also control for banks' business model. We make use of the ratio of net interest income to net operating income, NII, to proxy bank business model. ${ }^{7}$ This variable is also a proxy of bank product diversification used in many studies (Stiroh (2004), Lepetit et al. (2008a, 2008b)), a lower value indicating stronger expansion towards nontraditional intermediation activities. In the case of U.S. banks, Stiroh (2004) finds that greater reliance on noninterest income, particularly trading revenue, is associated with higher risk and lower risk-adjusted profits. Lepetit et al. (2008a) find that a heavier engagement in commission and fee activities implies

\footnotetext{
${ }^{6}$ Table A1 in appendix A presents the correlation matrix of the independent variables used in this study. The correlation coefficients are low except for bank size as measured by the natural logarithm of total assets (LTA) and the ratio of equity to total assets (EQTA). To see if the correlation between these variables affects our results, we have separately introduced total assets $(L T A)$ and the ratio of equity to total assets $(E Q T A)$ as independent variables. We have also estimated another equation where we have orthogonalized LTA with the ratio of equity to total assets $(E Q T A)$. These specifications lead to results qualitatively similar to those obtained by simultaneously introducing LTA and EQTA. Thus, the results presented in the paper are those obtained without orthogonalizing these two variables.

${ }^{7}$ As a robustness check, we use the ratio of net loans to total assets as an alternative proxy for the bank business model. The results do not qualitatively change and are available on request.
} 
higher risk for western European banks. Thus, we expect that, ceteris paribus, banks with a higher ratio of net interest income to net operating income will be less risky. Differences in ownership can also affect bank risk. Specifically, we consider the influence of state ownership. We construct a dummy variable (STATE), that takes the value of 1 if the share of state ownership in bank total ownership is higher than 50 percent, and zero otherwise. Several studies have found that state ownership leads to inefficiency and poor performance. For example Barth et al. (2004) and Berger et al. (2005) find that state-owned banks have higher ratios of non-performing loans to total loans. This can be explained by the fact that the managers of such banks are often under pressure to serve particular political interests.

We also control for the existence of state saving banks. These banks were the only or the most important suppliers on the interbank market. Besides, they benefited from full state deposit guarantee. To control for these specificities, we identify these state saving banks ${ }^{8}$ and construct a dummy variable (SAVING) that takes the value of 1 if the bank is a state saving bank. $^{9}$

\subsubsection{Country characteristics}

We also consider country-level variables that might affect bank risk. ${ }^{10}$ We take into account the annual growth rate of the real Gross Domestic Product (GDPG) to control for business cycle fluctuations and the overall economic conditions. Demirgüc-Kunt and Detragiache (2000) suggest that risk-taking incentives of banks managers might depend on

\footnotetext{
${ }^{8}$ The state saving banks indentified in our sample are: DSK Bank Plc (Bulgaria), Ceska Sporitelna a.s (Czech Republic), Eesti Hoiupank - IAS-Estonian Savings Bank - IAS (Estonia), OTP Bank Plc (Hungary), Latvijas Kraj Banka-Latvian Savings Bank (Latvia), Swedbank AB (Lithuania), Powszechna Kasa Oszczednosci Bank Polski SA - PKO BP SA and Bank Polska Kasa Opieki SA-Bank Pekao SA (Poland), Casa de Economii si Consemnatiuni-Romanian Savings Bank (Romania), Slovenska sporitel'na as-Slovak Savings Bank (Slovakia).

${ }^{9}$ We check the status of these banks each year. The dummy variable $S A V I N G_{i t}$ takes the value of one for bank $i$ on year $t$ only if bank $i$ is a state saving bank on year $t$. As a robustness check, we consider another definition for the state saving bank dummy variable. We assign the value one during the entire period for the identified state saving banks. As such, we consider that former state saving banks could still be different from other banks notably in terms of risk taking. Considering this alternative definition leads to similar conclusions. We also check that introducing both SAVING and STATE in our regressions is acceptable regarding colinearity issues. The correlation coefficient between these two variables is equal to 0.289 (Appendix A). Running our regressions without STATE or without SAVING does not impact our conclusions. The results are available on request.

${ }^{10}$ Alternatively, we have considered country characteristics through the introduction of country dummies. Our conclusions remain unchanged (see robustness checks in section 5). However, as it is not possible to introduce both country dummies and country-level indexes because of colinearity issues, we only consider country level indexes.
} 
the quality of law enforcement. We therefore control for the quality of law enforcement using the summary measure of law and order $(L A W)$ that we borrow from Pistor et al. (2000). A higher index reflects a higher quality of law enforcement and reduces incentives to engage in fraud and strategic default at the expense of creditors. We also control for the design of the deposit insurance regime as in Pasiouras et al. (2006). We construct a dummy variable reflecting the power of the deposit insurance authority $(D I P O W)$. This dummy variable takes the value 1 if the power of the deposit insurance authority is high and 0 otherwise. ${ }^{11} \mathrm{We}$ expect that a more powerful insurer is more likely to tackle moral hazard issues and that banks engage in lower risk taking in a country with a stronger deposit insurance authority. Finally, to account for differences across countries in terms of resolution strategies adopted when the country has experienced banking crises or severe banking distress, we include a dummy variable (RESOL). Indeed, according to Tang et al. (2000) and Dinger and Von Hagen (2009), the crisis resolution strategies pursued by the countries of our sample fall into two broad categories: (i) extensive restructuring and recapitalization of banks which corresponds to Bulgaria, Czech Republic, Hungary, Lithuania, Poland, and Slovakia which were reluctant to let incumbent banks fail and (ii) a combination of bank liquidation and restructuring for Estonia, Latvia, Romania, and Slovenia. The dummy variable RESOL takes the value of one for banks from countries that have proceeded to a combination of bank liquidation and restructuring, and zero otherwise. Claessens and Laeven (2003) show that different approaches in terms of resolution of banking crises have led to very different outcomes in terms of economic growth after the crisis. We assume that these specificities could affect bank risk-taking incentives and that such incentives should be lower in countries that have experienced actual liquidations. ${ }^{12}$

\section{3. $\quad$ Method}

To examine the impact of interbank deposits on bank risk, we estimate the following panel data model:

\footnotetext{
${ }^{11}$ Deposit insurer power is determined by adding 1 if the answer is yes and zero otherwise for each of the following questions: (1) Does the deposit insurance authority make the decision to intervene in a bank? (2) Can the deposit insurance agency take legal action against bank directors/officials? (3) Has the deposit insurance agency ever taken any legal action against bank directors/officials? The dummy variable DIPOW takes the value of one if the deposit insurer power is high that is if the number of "yes" answers is 2 or 3 , and 0 otherwise.

${ }^{12}$ Note that the summary measure of law and order (LAW), the deposit insurer power (DIPOW) and the banking crisis resolution strategies (RESOL) are not time-varying variables.
} 


$$
\operatorname{RISK}_{i, j, t}=\alpha_{0}+\alpha_{1} M K D_{i, j, t}+\beta^{\prime} X_{i, j, t}+\beta_{2}^{\prime} Z_{j, t}+\eta_{i}+\tau_{t}+u_{i, j, t}
$$

with $\operatorname{RISK}_{i, j, t}$ a proxy for bank $i$ risk taking in country $j$ at time $t ; M K D_{i, j, t}$ a variable reflecting market discipline, $X_{i, j, t}$ a collection of variables that capture bank i characteristics at time $\mathrm{t}$ in country $\mathrm{j} ; Z_{j, t}$ a vector of factors at the country level such as macroeconomic and institutional environment factors that are expected to affect bank risk at time t. $\alpha_{\mathrm{k}}$ and $\beta_{\mathrm{h}}^{\prime}$ are vectors of parameters and $\eta_{i}$ and $\tau_{t}$ the individual and time fixed effects. ${ }^{13}$

A necessary condition for market discipline to be effective is that some creditors are credibly excluded from any guarantee. Before the introduction of explicit deposit insurance implicit guarantees were broad. The introduction of explicit deposit insurance by credibly excluding some creditors from the guarantee is expected to favor the effectiveness of market discipline. Thus, we consider the disciplinary effect of interbank deposits when they are explicitly excluded from the guarantee that is after the introduction of explicit deposit insurance. For countries where explicit deposit insurance was introduced before 1996 (Czech Republic, Hungary, and Poland), the estimation is computed on the entire sample period (1995-2006). If explicit deposit insurance was introduced after 1995 (Bulgaria, Lithuania, Romania, Slovakia, Estonia, Latvia, and Slovenia), the estimation period begins with the introduction of explicit deposit insurance ${ }^{14}$

In our sample several banks have experienced mergers or acquisitions during the 1995-2006 period. It seems inappropriate to calculate mean values or standard deviations to compute our dependent variables for such banks as their balance sheets have been totally modified by these events. Instead of removing these banks from our sample, we split them into two different entities ${ }^{15}$ : we consider the bank after the merger or acquisition as a bank different from the one before the event. This applies to 19 banks in our sample.

\footnotetext{
${ }^{13}$ The regressions include individual and time fixed effects as the Fisher test rejects the null hypothesis of homogeneity in both individual and time dimensions.

${ }^{14}$ See footnote 5 .

15 This is done only if the merger or acquisition takes place after 1995 and before 2005 in order to be able to compute our dependent variables which are based on standard deviations. If it is not the case, we do not split the bank into two entities but we delete the observations before the event if it takes place before 1996 or the observations after the event if it takes place after 2004
} 
The descriptive statistics of our variables indicate highly skewed and heavy tails distribution of variables suggesting the presence of outliers. Thus, we follow John et al. (2008) and conduct residual diagnostic analyses and exclude outliers. ${ }^{16}$ In the regression with the standard deviation of ROA (SDROA) as a proxy of risk taking, 67 observations are excluded. In the regression with the standard deviation of ROE (SDROE) as a proxy of risk taking, 45 observations are excluded and 33 observations in the regression with the Z-SCORE as a proxy of default risk.

Finally, equation (1) is estimated on the sample excluding outliers with standard errors robust to heteroskedasticity. ${ }^{17}$

\section{Empirical results}

\subsection{Effectiveness of interbank deposits as a market discipline factor}

The results of the impact of interbank deposits on bank risk-taking are presented in Table $3 .{ }^{18}$ For each of the reported specifications, we find that the market discipline variable $(M K D)$ is significant. A higher proportion of interbank deposits translates into lower levels of bank risk taking and a lower probability of failure. This effect is not only statistically

\footnotetext{
${ }^{16}$ In order to detect outliers, we run OLS regressions and calculate the Cook's values. Cook's value (D) for the $i^{\text {th }}$ observation is a measure of the distance between the coefficient estimates when observation $i$ is included and when it is not, and it is defined as $\mathrm{D}_{\mathrm{i}}=\frac{\mathrm{e}_{\mathrm{si}}^{2}\left(\mathrm{~s}_{\mathrm{pi} /} \mathrm{s}_{\mathrm{ri}}\right)^{2}}{\mathrm{k}}$; where $\mathrm{e}_{\mathrm{si}}$ refers to standardised residuals, $\mathrm{S}_{\mathrm{ri}}$ to standard errors of the residuals and $\mathrm{s}_{\mathrm{pi}}$ to the standard errors of the prediction. $\mathrm{k}$ represents the number of independent variables plus the intercept term. High values of Cook's distance imply that $i^{\text {th }}$ observation has significant influence on estimation results, therefore, can be deemed to be an outlier. For more details see Cook and Weisberg (1982). Then, we drop any observation if its Cook's value is greater than $4 / n$, where $n$ is the number of observations in the regression (see Hamilton (2006) for more details).

${ }_{17}$ Alternatively, we have kept outliers and run outliers robust estimation, by following Covitz and Downing (2007), Laeven and Levine (2009) and Houston et al. (2010) and using the natural logarithm of the bank risk measures (Z-SCORE), the standard deviation of the return on assets (SDROA) and the standard deviation of the return on equity $(S D R O E))$ to limit the impact of outliers. This method leads to similar conclusions.

${ }_{18}$ All our regressions are run under explicit deposit insurance as mentioned in 3.1 and 3.3. It ensures that interbank deposits are explicitly excluded from guarantee. Indeed, before the introduction of explicit deposit insurance, implicit guarantees were broad which should deter market discipline. We have tested the influence of the introduction of explicit deposit insurance on market discipline by running our regressions on the whole period (1995-2006) for all countries and controlling for the existence of explicit deposit insurance. The results that are presented in Appendix B confirm that market discipline is only effective in the presence of explicit deposit insurance.
} 
significant but also economically noteworthy. Indeed, considering the specification where the risk-taking proxy is the standard deviation of $R O E$ (SDROE), a one standard deviation increase in interbank deposits $(M K D)$ decreases the risk-taking proxy by $20.88 \%$ of its mean (from 7.99 to 6.32). ${ }^{19}$ The concomitant drop in the standard deviation of ROA (SDROA) amounts to $17.71 \%$ of its mean (from 1.05 to 0.87 ). The economic impact of interbank deposit on the insolvency risk proxy (Z-SCORE) is also important. Indeed, a one standard deviation increase in interbank deposit is associated with an increase in the Z-SCORE of $10.33 \%$ of its mean (from 33.11 to 36.53 ).

Finally, the regressions results indicate that market discipline is effective and leads to a reduction in banks' riskiness and an improvement of their solvency.

As far as control variables computed at the bank level are concerned, we find that bank size measured by the natural logarithm of total assets (LTA), has a positive and significant effect on Z-SCORE, and a negative and significant effect on the standard deviation of return on assets (SDROA) and on the standard deviation of return on equity (SDROE). These results indicate that larger banks take less risk and are less vulnerable (lower default probability). The ratio of equity to total assets (EQTA) has also a significant effect on bank risk-taking measures. Indeed, as expected, we find a positive and significant relationship with the ZSCORE and a negative and significant relationship with the standard deviation of the ROE (SDROE) and the standard deviation of the ROA (SDROA), which suggests that better capitalized banks are less vulnerable and take less risk. The dummy variable STATE is negatively and significantly related to the standard deviation of the ROE (SDROE). Unexpectedly, state owned banks appear to take less risk than other banks possibly because most banks that are not owned by the state are foreign institutions. As noted by Mian (2006), foreign banks may actually have a preference for higher risk locally as they can more easily diversify themselves internationally. ${ }^{20}$ Similarly, state saving banks appear less risky as the dummy variable controlling for these banks $(S A V I N G)$ has a significant and negative effect on the standard deviation of ROA (SDROA). As expected, the business model proxy, i.e. the ratio

\footnotetext{
${ }^{19}$ Note that the mean values of our risk-taking and insolvency risk proxies are slightly different from the values reported in Table 2 (descriptive statistics) because of the use of unbalanced panel data and outliers' diagnostic method in our regressions.

${ }^{20}$ A closer look at the descriptive statistics of state-owned banks and those of privately owned banks shows that the dispersion of returns of state-owned banks is lower than that of private banks, but also that state-owned banks exhibit a lower profitability measured by the return on equity. Thus, lower risk taking by state-owned banks may be explained by the fact that these banks engage in activities with lower returns.
} 
of net interest income to total operating income (NII) has a negative coefficient in the regression with the standard deviation of ROA (SDROA) as the dependent variable, indicating that banks with a higher ratio of net interest income to total operating income are less risky.

Considering the control variables at the country level, several appear significant. The annual growth rate of the real Gross Domestic Product $(G D P G)$ and the law index $(L A W)$ are significant, whatever the dependent variable, with the expected sign indicating that higher quality of law enforcement and higher annual growth rate of the GDP are associated with lower risk-taking and lower default probability. The resolution strategy variable RESOL also affects both the insolvency risk of the bank as measured by the Z-SCORE and its asset risk as measured by the standard deviation of the ROE (SDROE) or ROA (SDROA). We find that banks' insolvency risk and asset risk are lower in countries that have experienced actual liquidations. The power of the deposit insurer $(D I P O W)$ also plays an important role as it is significantly linked with both the standard deviation of the ROE (SDROE) and the standard deviation of the ROA (SDROA). Banks in countries with higher power of the deposit insurance authority take less risk.

By comparing the impact of our dummy variables reflecting institutional and bank specific factors, we find that in countries that have experienced actual liquidations the standard deviation of ROE (SDROE) is reduced by 6.540 whereas a high power of the deposit insurer allows a larger decrease of the standard deviation of ROE (8.399). State ownership allows a slightly lower decrease in bank risk taking, as measured by the standard deviation of ROE, by 5.849. Considering the standard deviation of ROA (SDROA) as the dependent variable, only the power of the deposit insurer (DIPOW) and the resolution strategy (RESOL) affect bank risk with a larger impact for the resolution strategy: in countries that have experienced actual liquidations the standard deviation of ROA (SDROA) is reduced by 1.028 and only by 0.376 when the power of the deposit insurer is high. Thus, the resolution strategy (RESOL) and the power of the deposit insurer $(D I P O W)$ are the factors that have the most important impact on bank risk. Considering banks' insolvency risk (Z-SCORE), among the dummy variables, only the resolution strategy has a significant impact.

\section{< Insert Table 3 >}

To summarize, our results indicate that market discipline is effective. The importance of interbank deposits in total liabilities has an effect both on bank risk and bank default probability. However, several features might affect the effectiveness of market discipline. 
Indeed, in presence of explicit deposit insurance the extent of the power of the insurer is expected to play an important role. The importance of state ownership might be also an important factor reflecting the existence of an implicit insurance through state guarantee. Finally, likelihood for uninsured creditors to actually suffer losses in case of bank failures might depend on the resolution strategies adopted in each country during the banking crises they experienced.

\subsection{Factors affecting the effectiveness of market discipline.}

Our main results indicate that interbank deposits play a disciplinary role in presence of an explicit deposit insurance scheme. In this section, we study if differences in bank ownership or differences in banking regulation and supervision across countries may influence the effectiveness of market discipline.

\subsubsection{Implicit insurance through state ownership}

First, we focus on the influence of state ownership on the effectiveness of market discipline. More precisely, we test the potential difference in market discipline effectiveness between state-owned banks and other banks. We hypothesize that state-owned banks may benefit from an implicit insurance from the government. Therefore, market discipline may be weaker for such banks.

To test this hypothesis in all our regressions, we interact the market discipline factor $(M K D)$ with the state ownership dummy variable (STATE). The results, presented in Table 4, are consistent with our hypothesis. Indeed, we find that, for private banks, our market discipline variable $(M K D)$ is significant in all the estimations. Based on the specification with the standard deviation of ROE (SDROE) as the dependent variable, a one standard deviation increase in interbank deposits $(M K D)$ decreases the risk-taking proxy by $23.88 \%$ of its mean for private banks. Regarding the standard deviation of ROA (SDROA) for private banks, the fall amounts to $24.58 \%$ of its mean. The economic impact of interbank deposits on the ZSCORE is also important for private banks, since a one standard deviation increase in interbank deposits is associated with an increase in the Z-SCORE of $11.07 \%$ of its mean.

However, the results of the test at the bottom of Table 4 indicate that the market discipline variable is not significant for state-owned banks. Therefore, market discipline is effective only for private banks and is associated with both a lower insolvency risk as measured by the $Z$ SCORE and lower risk taking measured by the standard deviation of the ROA (SDROA) and 
the standard deviation of the ROE (SDROE). This result suggests that, uninsured creditors perceive the existence of an implicit insurance for state-owned banks and do not exert market discipline on them.

\section{< Insert Table 4 >}

\subsubsection{Deposit insurer power}

We now explore how market discipline might be affected by the deposit insurer power. Indeed, both markets and regulators impose a discipline. Markets penalize banks for increasing risk by increasing the costs of their market funding and by limiting the types of claims they can issue. Regulators impose discipline through risk-based capital requirements and insurance premiums, examination frequency and intensity, and cease and desist orders. We assume that the effectiveness of market discipline declines as the regulatory discipline is stronger (Billett et al. (1998)). Indeed, the incentives of market agents to intensively monitor and discipline banks could be weaker when regulators impose a stronger and tighter supervision. As such, regulatory discipline can, to some extent, be considered as a substitute for market discipline. As the deposit insurance scheme is one of the components of regulatory discipline, we conjecture that strong deposit insurer power undermines market discipline. We test this hypothesis by interacting the market discipline factor with the deposit insurer power dummy variable $(D I P O W)$. The empirical results are reported in Table 5.

\section{< Insert Table 5 >}

Table 5 shows, as previously, that stronger deposit insurer power $(D I P O W)$ is significantly associated with lower risk taking. Besides, market discipline is effective to reduce bank risk taking measured by the standard deviation of ROE (SDROE) or ROA (SDROA) when the power of the deposit insurer is low. A one standard deviation increase in interbank deposits $(M K D)$ reduces SDROE by $22.93 \%$ of its mean and SDROA by $15.62 \%$ of its mean for banks located in countries with low deposit insurer power.

By contrast, the results of the tests at the bottom of Table 5 indicate that the market discipline variable is not significant when the power of the deposit insurer is high. This result confirms 
that strong deposit insurer power undermines market discipline. When the extent of the insurer's attributions is higher, the market appears to have lower incentives to monitor banks.

\subsubsection{Banking crisis resolution strategies}

All the countries in our sample experienced a systemic banking crisis or at least borderline and small (non-systemic) banking crises, before or at the beginning of our sample period. As noted above, these countries have followed different strategies in managing these crises. We explore whether the effect of market discipline is different for countries which have proceeded to massive recapitalizations and those which have adopted a mix of liquidation and restructuring. We hypothesize that the disciplining effect of interbank deposits will be higher in countries that have pursued liquidation than in those which have followed recapitalization policies. Indeed, creditors might fear losing their wealth in case of bank liquidation if they assume that the same resolution strategy would be adopted in case of crisis.

We examine this hypothesis by interacting the resolution strategy dummy variable (RESOL) with the market discipline factor $(M K D)$, where RESOL equals one for countries which have adopted a mix of liquidation and restructuring to manage banking crises, and zero for those which have adopted recapitalization and restructuring. As shown by Table 6, the results indicate that market discipline is less effective in countries that had enforced bank liquidation policies in previous episodes of banking distress. Indeed, the market discipline factor is effective $(M K D)$ in all specifications for countries that have adopted recapitalization and restructuring. A one standard deviation increase in interbank deposits (MKD) decreases the standard deviation of ROE (SDROE) by $18.75 \%$ of its mean and the standard deviation of ROA (SDROA) by $16.91 \%$ of its mean for banks located in countries that have undergone recapitalizations and restructuring in managing banking crises. Regarding the default risk the Z-SCORE is reduced by $14.71 \%$ of its mean. By contrast, for countries that have adopted a mix of liquidation and restructuring, the sum of the coefficients of the interaction term and the market discipline variable is significant only with the standard deviation of ROE (SDROE) as the dependent variable. Thus, market discipline leads to a lower risk taking of banks in countries that have proceeded to liquidations but it does not affect their insolvency risk.

These results are not consistent with the assumption that countries that have pursued liquidation policies should exhibit higher market discipline. However, as discussed in section 4.2.2, stronger regulatory discipline is also expected to undermine market discipline. Indeed, 
when banks are supervised by a strict regulator that is known to liquidate an institution in the event of insolvency, the fear of punishment might lead banks to take less risk in the first place. This might weaken the incentives of market agents to discipline banks. Thus, our variable RESOL might reflect the strength of regulatory discipline rather than the credibility of non bail-out policies. As shown in Table 3, banks' insolvency risk (Z-SCORE) and asset risk (SDROE and SDROA) are lower in countries that have experienced actual liquidations. Thus, market discipline may be weaker, given the role played by the discipline introduced by the regulator.

\section{< Insert Table 6>}

\section{Robustness checks}

To check the robustness of our results, we conduct several sensitivity analyses.

First, we compute our dependent variables on 4-year rolling windows (see appendix C). The results are highly consistent with our previous findings regarding the effectiveness of market discipline and the impact of deposit insurer power, state ownership and resolution strategies.

Second, to control for specificities at the country level, we exclude all country-level indexes used as control variables and replace them by country dummies. ${ }^{21}$ Considering these alternative control variables leads to similar results. ${ }^{22}$

Third, to check the robustness of the deeper investigations on the effectiveness of market discipline, we run the regressions on sub-samples. Firstly, we separate countries that have high deposit insurer power $(D I P O W=1)$ from countries with low deposit insurer power

\footnotetext{
${ }^{21}$ Alternatively, it could be interesting to run single country regressions. However, we do not have enough observations for most of the countries in our sample. As a robustness check, we have analyzed the impact of market discipline on bank risk taking in Hungary (by running regressions on a sample restricted to banks located in Hungary). Indeed, Hungary is the country for which we have the highest number of observations with a stable number of banks on our sample period. Besides, our sample of Hungarian banks represents over $80 \%$ of the total Hungarian commercial banks' assets. Running regressions on this single country leads to the same conclusion concerning the impact of market discipline on bank risk taking. We cannot analyze the impact of state ownership on the effectiveness of market discipline as this variable is not introduced in the regressions due to colinearity issues. Besides, as the deposit insurer power (DIPOW) and the banking crisis resolution strategies (RESOL) are not time-varying variables, it is not possible to measure their impact on market discipline in a within-country study.

${ }^{22}$ Results are available upon request.
} 
$(D I P O W=0)$. We still find that market discipline is effective to reduce bank risk when the power of the insurer is low. When the power of the insurer is high, the market discipline variable is significant only with the standard deviation of the ROA (SDROA) as the dependent variable and only at the $10 \%$ level of significance (see Panel A in appendix D). Secondly, we separate countries that have conducted liquidation and restructuring $(R E S O L=1)$, from countries that have conducted extensive recapitalizations and restructuring $(R E S O L=0)$. On the whole, our results remain the same. Market discipline is weaker in countries that have experienced a mix of bank liquidations and restructuring than in countries that have pursued recapitalization and restructuring policies (see Panel B in the appendix D). ${ }^{23}$

Fourth, we consider another threshold to construct the dummy variable STATE. Banks are considered state owned if at least $30 \%$ of the shares are controlled by the state. We construct the dummy variable STATE2 with this new definition. Considering this dummy variable leads to similar results (see appendix E).

Fifth, we run the regressions excluding the banks that have experienced mergers or acquisitions during the period 1995-2006. This leads us to eliminate 19 banks. Our main conclusions remain unchanged. ${ }^{24}$

\section{Conclusion}

The purpose of this study is to assess the disciplinary role of interbank deposits as well as the institutional and bank specific factors affecting its effectiveness. Using a sample of 207 banks from 10 countries of Central and Eastern Europe, we find, by controlling for various factors, that interbank deposits do play a disciplinary role in the presence of explicit insurance and refrain banks from excessive risk taking.

Our results also indicate that the market is more lenient with state owned-banks possibly because they are perceived as implicitly insured by the government even in the presence of explicit limited insurance. We also find that the extent of the insurer's power impacts market discipline: market discipline is effective only when deposit insurer power is low suggesting that the presence of a more powerful insurer undermines market discipline by

\footnotetext{
${ }^{23}$ We do not separately run regressions on a sub-sample restricted to state-owned banks and a sub-sample including private banks only because of an insufficient number of observations for the sub-sample of stateowned banks.

${ }^{24}$ Results are available upon request.
} 
lowering the incentives of market participants to monitor banks. We consistently find that banks take less risk in countries with more powerful deposit insurers. Finally, we also show that when banks are supervised by a regulator that is more likely to liquidate failing institutions rather than to rescue them, they are less risky and market discipline is weaker: stronger regulatory discipline might be undermining market discipline. 


\section{APPENDIX A}

Table A1: Correlations between Independent Variables.

\begin{tabular}{|c|c|c|c|c|c|c|c|c|c|c|}
\hline & MKD & EQTA & LTA & STATE & NII & SAVING & GDPG & RESOL & LAW & DIPOW \\
\hline MKD & 1 & & & & & & & & & \\
\hline EQTA & -0.065 & 1 & & & & & & & & \\
\hline LTA & -0.081 & -0.528 & 1 & & & & & & & \\
\hline STATE & 0.009 & 0.000 & 0.136 & 1 & & & & & & \\
\hline NII & 0.047 & 0.058 & 0.041 & -0.081 & 1 & & & & & \\
\hline SAVING & -0.109 & -0.084 & 0.208 & 0.289 & 0.080 & 1 & & & & \\
\hline GDPG & -0.119 & 0.010 & -0.018 & -0.091 & 0.081 & 0.032 & 1 & & & \\
\hline RESOL & -0.188 & 0.086 & -0.122 & -0.036 & -0.018 & -0.027 & 0.314 & 1 & & \\
\hline LAW & 0.231 & -0.205 & 0.273 & -0.030 & -0.097 & 0.029 & -0.142 & -0.218 & 1 & \\
\hline DIPOW & 0.046 & -0.124 & 0.151 & -0.084 & 0.046 & 0.008 & -0.179 & -0.162 & 0.211 & 1 \\
\hline
\end{tabular}

$M K D=$ interbank deposits to total deposits ratio; $E Q T A=$ equity to assets ratio; $N I I=$ ratio of net interest income to total operating income; $L T A=$ logarithm of total assets; $G D P G=$ growth rate of real GDP; DIPOW = power of deposit insurance authority dummy variable. This dummy variable takes the value of one for countries that have a deposit insurance authority power index equals two or more, and zero otherwise; $R E S O L=$ crises resolution strategies dummy variable that takes the value of 1 for country having proceeded to a combination of bank liquidation and restructuring, and 0 for country having made extensive restructuring and recapitalization of banks; $L A W=$ rule of law. This variable takes value between 1 and 10 , higher values suggesting a higher quality of law enforcement; STATE = state owned bank dummy variable. This dummy variable takes the value of one for banks in which state ownership represents at least 50 percent of total share, and zero otherwise; SAVING = state saving bank dummy variable. This dummy variable takes the value of one if the bank is a state saving bank on the year considered, and zero otherwise. 


\section{APPENDIX B}

\section{TABLE B1: Impact of explicit deposit insurance on market discipline.}

Model specification:

$$
\operatorname{RISK}_{i, j, t}=\alpha_{0}+\alpha_{1} \operatorname{DEPINS}+\alpha_{2} \operatorname{MKD}_{i, j, t}+\alpha_{3}(\operatorname{DEPINS} * M K D)+\dot{\beta}_{1}^{\prime} X_{i, j, t}+\dot{\beta}_{2}^{\prime} Z_{j, t}+\eta_{i}+\tau_{t}+\gamma_{j}+u_{i, j, t}
$$

\begin{tabular}{llll}
\hline VARIABLES & SDROE & SDROA & Z-SCORE \\
\hline DEPINS & $9.489^{* * *}$ & $1.049 * * *$ & $-14.400^{*}$ \\
& $(4.410)$ & $(3.671)$ & $(-1.730)$ \\
MKD & 0.096 & -0.010 & 0.085 \\
& $(0.823)$ & $(-0.983)$ & $(0.244)$ \\
DEPINS*MKD & -0.158 & 0.005 & 0.026 \\
& $(-1.361)$ & $(0.430)$ & $(0.0766)$ \\
\hline$\alpha_{2}+\alpha_{3}$ & $-0.062^{* * *}$ & $-0.006^{*}$ & 0.111 \\
Risk level to reject $: \alpha_{2}+\alpha_{3}=0$ & 0.007 & 0.096 & 0.148 \\
\hline OBSERVATIONS & 1142 & 1170 & 1156 \\
R-SQUARED & 0.559 & 0.570 & 0.425 \\
\hline
\end{tabular}

The regressions contain the same control variables as those in Table 3 except that we control for country specificities by introducing country dummy variables instead of country-level invariant variables. We report only the coefficients on explicit deposit insurance scheme dummy variable, market discipline factor and the interaction term (explicit deposit insurance scheme dummy variable and the market discipline factor). Detailed results are available upon request.

$S D R O A=$ standard deviation of the ROA; SDROE = standard deviation of the ROE; Z-SCORE = bank insolvency risk; $D E P I N S=$ explicit deposit insurance scheme. This dummy variable takes the value of one if there is an explicit deposit insurance scheme on the considered year and 0 otherwise; $M K D=$ interbank deposits to total deposits ratio. Bank, time and country fixed effects are included but not reported. Robust t-statistics are in parentheses. *, **, *** represent statistical significance at the $10 \%, 5 \%$, and $1 \%$ levels, respectively. 


\section{APPENDIX C}

\section{Table C1: Regressions using dependent variables computed on 4-year rolling windows}

Panel A model specification: $R I S K_{i, j, t}=\alpha_{0}+\alpha_{1} M K D_{i, j, t}+\beta_{1}^{\prime} X_{i, j, t}+\beta_{2}^{\prime} Z_{j, t}+\eta_{i}+\tau_{t}+u_{i, j, t}$

Panel B, C and D model specification: $R I S K_{i, j, t}=\alpha_{0}+\alpha_{1} M K D_{i, j, t}+\alpha_{2}(D U M * M K D)+\beta_{1}^{\prime} X_{i, j, t}+\beta_{2}^{\prime} Z_{j, t}+\eta_{i}+\tau_{t}+u_{i, j, t}$ with DUM= DIPOW, RESOL, and STATE respectively

\begin{tabular}{|c|c|c|c|c|c|c|c|c|c|c|c|c|}
\hline \multirow[b]{2}{*}{ VARIABLES } & \multicolumn{3}{|c|}{$\begin{array}{l}\text { Panel A:Effectiveness of interbank } \\
\text { deposits as market discipline factor }\end{array}$} & \multicolumn{3}{|c|}{$\begin{array}{l}\text { Panel B:Influence of the deposit } \\
\text { insurer power on the effectiveness of } \\
\text { market discipline }\end{array}$} & \multicolumn{3}{|c|}{$\begin{array}{l}\text { Panel C:Influence of the banking } \\
\text { crisis resolution strategy on the } \\
\text { effectiveness of market discipline }\end{array}$} & \multicolumn{3}{|c|}{$\begin{array}{l}\text { Panel D:Influence of implicit } \\
\text { insurance through state ownership on } \\
\text { the effectiveness of market discipline }\end{array}$} \\
\hline & SDROE & SDROA & Z-SCORE & SDROE & SDROA & Z-SCORE & SDROE & SDROA & Z-SCORE & SDROE & SDROA & Z-SCORE \\
\hline MKD & $\begin{array}{c}-0.061 * * \\
(-2.524)\end{array}$ & $\begin{array}{l}-0.006^{*} \\
(-1.823)\end{array}$ & $\begin{array}{l}0.028 \\
(0.590)\end{array}$ & $\begin{array}{c}-0.069 * * * \\
(-2.754)\end{array}$ & $\begin{array}{l}-0.007 * \\
(-1.948)\end{array}$ & $\begin{array}{c}0.043 \\
(0.789)\end{array}$ & $\begin{array}{l}-0.062 * * \\
(-2.219)\end{array}$ & $\begin{array}{l}-0.007 * \\
(-1.824)\end{array}$ & $\begin{array}{c}0.087 \\
(1.472)\end{array}$ & $\begin{array}{c}-0.065^{* * *} \\
(-2.585)\end{array}$ & $\begin{array}{c}-0.009 * * \\
(-2.561)\end{array}$ & $\begin{array}{c}0.049 \\
(1.012)\end{array}$ \\
\hline DIPOW & $\begin{array}{c}-26.760 * * * \\
(-13.680)\end{array}$ & $\begin{array}{c}-1.514 * * * \\
(-2.600)\end{array}$ & $\begin{array}{c}55.950 * * * \\
(14.930)\end{array}$ & $\begin{array}{c}-27.540 * * * \\
(-10.950)\end{array}$ & $\begin{array}{c}-3.180 * * * \\
(-9.048)\end{array}$ & $\begin{array}{l}15.760 * \\
(1.933)\end{array}$ & $\begin{array}{c}-26.700 * * * \\
(-13.240)\end{array}$ & $\begin{array}{c}-3.085 * * * \\
(-9.812)\end{array}$ & $\begin{array}{c}54.160 * * * \\
(14.300)\end{array}$ & $\begin{array}{c}-26.820 * * * \\
(-13.490)\end{array}$ & $\begin{array}{r}-3.054 * * * \\
(-10.270)\end{array}$ & $\begin{array}{c}56.990 * * * \\
(14.860)\end{array}$ \\
\hline DIPOW*MKD & & & & $\begin{array}{c}0.026 \\
(0.499)\end{array}$ & $\begin{array}{c}0.002 \\
(0.303)\end{array}$ & $\begin{array}{l}-0.057 \\
(-0.607)\end{array}$ & & & & & & \\
\hline RESOL & $\begin{array}{c}-14.620 * * * \\
(-7.163)\end{array}$ & $\begin{array}{c}-1.116 * * * \\
(-4.003)\end{array}$ & $\begin{array}{l}35.310 * * * \\
(6.542)\end{array}$ & $\begin{array}{c}-14.550 * * * \\
(-7.181)\end{array}$ & $\begin{array}{l}-0.860^{*} \\
(-1.694)\end{array}$ & $\begin{array}{l}23.820 * * * \\
(4.157)\end{array}$ & $\begin{array}{c}-14.770 * * * \\
(-6.285)\end{array}$ & $\begin{array}{l}-0.962 * \\
(-1.810)\end{array}$ & $\begin{array}{c}41.410 * * * \\
(6.960)\end{array}$ & $\begin{array}{c}-14.410 * * * \\
(-6.934)\end{array}$ & $\begin{array}{l}-0.528 \\
(-1.125)\end{array}$ & $\begin{array}{c}34.870 * * * \\
(6.404)\end{array}$ \\
\hline RESOL*MKD & & & & & & & $\begin{array}{c}0.005 \\
(0.102)\end{array}$ & $\begin{array}{c}0.004 \\
(0.630)\end{array}$ & $\begin{array}{c}-0.227 * * \\
(-2.170)\end{array}$ & & & \\
\hline STATE & $\begin{array}{c}-4.940 * * \\
(-2.414)\end{array}$ & $\begin{array}{c}-0.175 \\
(-0.394)\end{array}$ & $\begin{array}{c}10.230 * * \\
(2.039)\end{array}$ & $\begin{array}{c}-4.935^{* *} \\
(-2.405)\end{array}$ & $\begin{array}{c}-0.179 \\
(-0.405)\end{array}$ & $\begin{array}{c}10.170^{* *} \\
(2.024)\end{array}$ & $\begin{array}{c}-4.935^{* *} \\
(-2.408)\end{array}$ & $\begin{array}{c}-0.175 \\
(-0.392)\end{array}$ & $\begin{array}{c}10.300 * * \\
(2.049)\end{array}$ & $\begin{array}{c}-6.269 * * \\
(-2.555)\end{array}$ & $\begin{array}{l}-0.790^{*} \\
(-1.795)\end{array}$ & $\begin{array}{c}16.440 * * * * \\
(2.602)\end{array}$ \\
\hline STATE*MKD & & & & & & & & & & $\begin{array}{c}0.064 \\
(1.015) \\
\end{array}$ & $\begin{array}{l}0.029 * \\
(1.751) \\
\end{array}$ & $\begin{array}{l}-0.327^{*} \\
(-1.852) \\
\end{array}$ \\
\hline$\alpha_{1}+\alpha_{2}$ & & & & -0.043 & -0.005 & -0.013 & -0.057 & -0.003 & -0.140 & $-0,001$ & 0,02 & $-0,278$ \\
\hline Risk level to reject : $\alpha_{1}+\alpha_{2}=0$ & & & & 0.385 & 0.462 & 0.864 & 0.179 & 0.625 & 0.108 & 0.981 & 0.216 & 0.110 \\
\hline OBSERVATIONS & 883 & 940 & 888 & 883 & 940 & 888 & 883 & 940 & 888 & 883 & 940 & 888 \\
\hline R-SQUARED & 0.682 & 0.781 & 0.618 & 0.682 & 0.781 & 0.618 & 0.682 & 0.781 & 0.621 & 0.682 & 0.783 & 0.620 \\
\hline
\end{tabular}

The regressions contain the same control variables as those in Tables 3 . We report only the coefficients on market discipline factor, dummy variable of interest, and the interaction term (dummy variable and the market discipline factor). Detailed results are available upon request. SDROA = standard deviation of the ROA; $S D R O E=$ standard deviation of the ROE. Z-SCORE $=$ bank insolvency risk; $M K D=$ interbank deposits to total deposits ratio. $D I P O W=$ power of deposit insurance authority dummy variable. This dummy variable takes the value of one for countries that have a deposit insurance authority power index equals two or more, and zero otherwise; RESOL = crises resolution strategies dummy variable that takes the value of 1 for country having proceeded to a combination of bank liquidation and restructuring, and 0 for country having made extensive restructuring and recapitalization of banks; STATE = state owned bank dummy variable. This dummy variable takes the value of one for banks in which state ownership represents at least 50 percent of total share, and zero otherwise. Bank and time fixed effects are included but not reported. Robust t-statistics are in parentheses. *, **, *** represent statistical significance at the 10\%, 5\%, and $1 \%$ levels, respectively. 


\section{APPENDIX D}

\section{Table D1: Regressions on sub-samples}

Panel A and B model specification:

$$
R I S K_{i, j, t}=\alpha_{0}+\alpha_{1} M K D_{i, j, t}+\dot{\beta}_{1}^{\prime} X_{i, j, t}+\dot{\beta}_{2}^{\prime} Z_{j, t}+\eta_{i}+\tau_{t}+u_{i, j, t}
$$

\begin{tabular}{lccc|ccc} 
& \multicolumn{2}{c}{ Panel A: Influence of the deposit insurer power on the effectiveness of market discipline } \\
\cline { 2 - 7 } & \multicolumn{2}{c}{ High deposit insurer power } & \multicolumn{3}{c}{ Low deposit insurer power } \\
\hline VARIABLES & SDROE & SDROA & Z-SCORE & SDROE & SDROA & Z-SCORE \\
\hline MKD & -0.073 & $-0.006^{*}$ & 0.230 & $-0.0427 * *$ & $-0.00960 * *$ & 0.0616 \\
& $(-1.236)$ & $(-1.661)$ & $(1.065)$ & $(-2.149)$ & $(-2.403)$ & $(0.747)$ \\
\hline Observations & 350 & 342 & 342 & 696 & 739 & 737 \\
R-squared & 0.513 & 0.654 & 0.442 & 0.632 & 0.650 & 0.468 \\
\hline
\end{tabular}

Panel B: Influence of the banking crisis resolution strategy on the effectiveness of market discipline

\begin{tabular}{|c|c|c|c|c|c|c|}
\hline \multirow[b]{2}{*}{ VARIABLES } & \multicolumn{3}{|c|}{$\begin{array}{l}\text { Countries having proceeded to a mix of } \\
\text { recapitalizations and liquidations }\end{array}$} & \multicolumn{3}{|c|}{ Countries having proceeded to recapitalizations } \\
\hline & SDROE & SDROA & Z-SCORE & SDROE & SDROA & Z-SCORE \\
\hline MKD & $\begin{array}{l}-0.094 * * \\
(-2.395) \\
\end{array}$ & $\begin{array}{l}-0.004 \\
(-0.799) \\
\end{array}$ & $\begin{array}{l}-0.039 \\
(-0.404) \\
\end{array}$ & $\begin{array}{l}-0.052 * * \\
(-2.045) \\
\end{array}$ & $\begin{array}{l}-0.009 * * \\
(-2.072)\end{array}$ & $\begin{array}{l}0.191 * \\
(1.818) \\
\end{array}$ \\
\hline OBSERVATIONS & 269 & 275 & 266 & 783 & 802 & 796 \\
\hline R-SQUARED & 0.803 & 0.827 & 0.681 & 0.441 & 0.592 & 0.436 \\
\hline
\end{tabular}

The regressions contain the same variables as those in Table 3 except the power of deposit insurance authority dummy variable in Panel A and the crises resolution strategies dummy variable in Panel B. Besides, the dummy variable SAVING is not included in the regressions on the sub-sample of banks located in countries with low deposit insurer power due to strong correlation between this variable and STATE and cannot be introduced on the sub-sample of banks located in countries that have proceeded to a mix of recapitalizations and liquidations (when the dependent variable is SDROE or Z-SCORE) due to colinearity issues. We report only the coefficients on market discipline factor. Detailed results are available upon request.

$S D R O A=$ standard deviation of the ROA; SDROE = standard deviation of the ROE; Z-SCORE = bank insolvency risk; $M K D$ $=$ interbank deposits to total deposits ratio. Bank and time fixed effects are included but not reported. Robust t-statistics are in parentheses. *,**, *** represent statistical significance at the $10 \%, 5 \%$, and $1 \%$ levels, respectively. The power of the deposit insurer is considered high for countries that have a deposit insurance authority power index equals two or more. It is considered low for countries that have a deposit insurance authority power index equals 0 or 1 . 


\section{APPENDIX E}

\section{Table E1: Regressions using another definition of state-owned banks.}

Model specification:

\begin{tabular}{llll}
$R I S K_{i, j, t}=\alpha_{0}+\alpha_{1} M K D_{i, j, t}+\alpha_{2}(S T A T E 2 * M K D)+\beta_{1}^{\prime} X_{i, j, t}+\beta_{2}^{\prime} Z_{j, t}+\eta_{i}+\tau_{t}+u_{i, j, t}$ \\
\hline VARIABLES & SDROE & SDROA & Z-SCORE \\
\hline MKD & $-0.085^{* * * *}$ & $-0.012^{* * *}$ & $0.157^{*}$ \\
& $(-3.200)$ & $(-3.488)$ & $(1.943)$ \\
STATE2*MKD & $0.188^{* * *}$ & $0.038^{* * *}$ & -0.199 \\
& $(3.312)$ & $(2.759)$ & $(-0.665)$ \\
STATE2 & $-9.949^{* * *}$ & $-1.136^{* * *}$ & $18.170^{* *}$ \\
& $(-4.305)$ & $(-2.868)$ & $(2.161)$ \\
\hline$\alpha_{1}+\alpha_{2}$ & $0.103 * *$ & $0.026 *$ & -0.042 \\
Risk level to reject $: \alpha_{1}+\alpha_{2}=0$ & 0.047 & 0.052 & 0.887 \\
\hline OBSERVATIONS & 1060 & 1083 & 1080 \\
R-SQUARED & 0.539 & 0.572 & 0.472
\end{tabular}

The regressions contain the same control variables as those in Table 3. We report only the coefficients on state-owned bank dummy variable, market discipline factor, and the interaction term (state owned bank dummy variable and the market discipline variable). Detailed results are available upon request.

$S D R O A=$ standard deviation of the ROA; SDROE = standard deviation of the ROE; Z-SCORE = bank insolvency risk; $M K D$ $=$ interbank deposits to total deposits ratio. STATE2 = state owned bank dummy variable. This dummy variable takes the value of one for banks in which state ownership represents at least 30 percent of total share, and zero otherwise. Bank and time fixed effects are included but not reported. Robust $\mathrm{t}$-statistics are in parentheses. *, **, *** represent statistical significance at the $10 \%, 5 \%$, and $1 \%$ levels, respectively. 


\section{Bibliography}

Angkinand, Apanard P., Wihlborg, Clas, 2010. Deposit Insurance Coverage, Ownership, and Banks' Risk-Taking in Emerging Markets. Journal of International Money and Finance 29, 201-386.

Bank for International Settlements (BIS), 2003. Markets for Bank subordinated Debt and Equity in Basel Committee Member Countries, Working Paper $n^{\circ} 12$.

Barth, James R., Caprio, Gerard Jr., Levine, Ross, 2003. The regulation and supervision of banks around the world: a new database (updated 2003). World Bank Policy Research Working Paper $\mathrm{n}^{\circ} 2588$.

Barth, James R., Caprio, Gerard Jr., Levine, Ross, 2004. Bank Regulation and Supervision: What Works Best? Journal of Financial Intermediation 13, 205-248.

Beck, Thorsten, Laeven, Luc, 2006. Resolution of Failed Banks by Deposit Insurers CrossCountry Evidence, World Bank Policy Research Working Paper n $^{\circ} 3920$.

Berger, Allen N., Clarke, George R. G., Cull, Robert, Klapper, Leora, Udell, Gregory F., 2005. Corporate Governance and Bank Performance: A Joint Analysis of the Static, Selection, and Dynamic Effects of Domestic, Foreign, and State Ownership. World Bank Policy Research Working Paper 3632.

Billett, Matthew T., Garfinkel, Jon A., O'Neal, Edward S., 1998. The cost of market versus regulatory discipline in Banking. Journal of Financial Economics 48, 333-358.

Boot, Arnoud W., Greenbaum, Stuart, 1993. Bank regulation, reputation and rents. In: Mayer,Colin, Vives, Xavier (Eds.), Capital Markets and Financial Intermediation. Cambridge University Press/ Cambridge, pp. 262-285.

Borisova, Ginka, Megginson, William L., 2012. Does government ownership affect the cost of debt? Evidence from privatization. Review of financial studies. Advanced Access published March 2, 2012.

Boyd, John H., Graham, Stanley L., Hewitt, Shawn R., 1993. Bank Holding Company Mergers with Nonbank Financial Firms: Effects on the Risk of Failure. Journal of Banking and Finance 17, 43-63.

Claessens, Stijn, Laeven, Luc, 2003. Financial Development, Property Rights, and Growth. Journal of Finance 58, 2401-2436.

Cocco, João F., Gomes, Francisco J., Martins, Nuno C., 2009. Lending Relationships in the Interbank Market. Journal of Financial Intermediation 18, 24-48.

Cook, R. D., Weisberg, S., 1982. Residuals and Influence in Regression. London: Chapman and Hall. 
Covitz, Dan, Downing, Chris, 2007. Liquidity or credit risk? Determinants of Very ShortTerm Corporate Yield Spread. Journal of Finance 62, 2303-2328.

Curry, Timothy J., Fissel, Gary S., Hanweck, Gerald A., 2008. Equity Market Information, Bank Holding Company Risk and Market Discipline. Journal of Banking and Finance 32, 807-819.

Demirgüc-Kunt, Asli, Detragiache, Enrica, 2000. Does Deposit insurance Increase Banking System Stability? An Empirical Investigation, IMF Working Paper No WP/00/03.

Demirgüc-Kunt, Asli, Karacaovali, Baybars, Laeven, Luc, 2005. Deposit insurance around the world: a comprenhensive database. World Bank Policy Research Working Paper $\mathrm{n}^{\circ} 3628$.

De Nicolò, Gianni, 2000. Size, Charter Value and Risk in Banking: An International Perspective. Board of Governors of the Federal Reserve System. International Finance Discussion Paper No. 689.

Dinger, Valeriya, Von Hagen, Jürgen, 2009. Does Interbank Borrowing Reduce bank Risk? Journal of Money, Credit and Banking 41, 491-506.

Flannery, Mark J., 2001. The Faces of Market Discipline. Journal of Financial Services Research 20, 107-119.

Flannery, Mark J., Sorescu, Sorin M., 1996. Evidence of bank market discipline in subordinated debenture yields: 1983-1991. Journal of Finance 54, 1347-1377.

Furfine, Craig H., 2001. Banks as Monitors of Other Banks: Evidence from the Overnight Federal Funds Market. Journal of Business, 74.

Galloway, Tina M., Lee, Winson B., Roden, Dianne M.,1997. Banks' Changing Incentives and Opportunities for Risk Taking. Journal of Banking and Finance 21, 509-527.

Gropp, Reint, Vesala, Jukka,Vulpes, Giuseppe, 2006. Equity and Bond Market Signals as Leading Indicators of Bank Fragility. Journal of Money, Credit and Banking 38, 399-428.

Hamalainen, Paul, Hall, Maximilian J.B., Howcroft, Barry J., 2005. A Framework for Market Discipline in Bank Regulatory Design. Journal of Business Finance and Accounting 32,183209.

Hamilton, Lawrence C., 2006 Statistics with STATA (updated for version 9). Thomson Books/Cole, pp. 196-214.

Hannan, Timothy H., Hanweck, Gerald A., 1988. Bank Insolvency Risk and the Market for Large Certificates of Deposit. Journal of Money, Credit and Banking 20, 203-11.

Houston, Joel F., Lin, Chen, Lin, Ping, Ma, Yue, 2010. Creditor rights, information sharing and bank risk taking, Journal of Financial Economics 96, 485-512. 
Jagtiani, Julapa A., Kaufman, George, Lemieux, Catharine M., 1999. Do markets discipline banks and bank holding companies? Evidence from debt pricing. Emerging Issues Working Papers, Federal Reserve Bank of Chicago.

John, Kose, Litov, Lubomir, Yeung, Bernard, 2008. Corporate Governance and Risk-taking, Journal of Finance 63, 1679-1728.

King, Thomas B., 2008. Discipline and Liquidity in the Interbank Market. Journal of Money, Credit and Banking 40, 295-317.

Laeven, Luc, Levine, Ross, 2009. Bank governance, regulation and risk taking. Journal of Financial Economics 93, 259-275.

Lepetit, Laetitia, Nys, Emmanuelle, Rous, Philippe, Tarazi, Amine, 2008a. Bank income structure and risk: An empirical analysis of European banks. Journal of Banking and Finance $32,1452-1467$.

Lepetit, Laetitia, Nys, Emmanuelle, Rous, Philippe, Tarazi, Amine, 2008b. The expansion of services in European banking: implications for loan pricing and interest margins. Journal of Banking and Finance 32, 2325-2335.

Martinez Peria, Maria S., Schmukler, Sergio L., 2001. Do depositors punish banks for bad behavior? Market discipline, deposit insurance, and banking crisis. Journal of Finance 56, 1029-1051.

Mian, Atif, 2006. Distance Constraints: The Limits of Foreign Lending in Poor Economies. Journal of Finance 61, 1465-1505.

Morgan, Donald P., Stiroh, Kevin J., 2001. Market Discipline of Banks: The Asset Test. Journal of Financial Services Research 20, 195-208.

Nier, Erlend, Baumann, Ursel, 2006. Market Discipline, disclosure and moral hazard in banking. Journal of Financial Intermediation 15, 332-361.

Pasiouras, Fotios, Gaganis, Chrysovalantis, Zopounidis, Constantin, 2006. The impact of bank regulations, supervision, market structure, and bank characteristics on individual bank ratings: A cross-country analysis. Review of Quantitative Finance and Accounting 27, 403438.

Pistor, Katharina, Raiser, Martin, Gelfer, Stanislaw, 2000. Law and Finance in Transition Economies Economics of Transition 8, 325-368.

Rochet, Jean, C., Tirole, Jean, 1996. Interbank Lending and Systemic Risk. Journal of Money, Credit and Banking, 28, 733-62.

Roy, Andrew D. 1952, Safety First and the Holding of Assets. Econometrica 20, 431-449.

Sironi, Andrea, 2003. Testing for Market Discipline in the European Banking Industry: Evidence from Subordinated Debt Issues. Journal of Money, Credit and Banking 35, 443-472. 
Stiroh, Kevin J., 2004. Diversification in banking: Is non-interest income the answer? Journal of Money, Credit and Banking 36,853-882.

Tang, Helena, Zoli, Edda, Klytchnikova, Irina, 2000. Banking Crises in Transition Countries: Fiscal costs and related issues. World Bank Working Paper, No. 2484. 
Table 1: Descriptive Statistics on Summary Accounting Information.

\begin{tabular}{|l|c|c|c|c|c|c|c|c|}
\hline & \multicolumn{3}{|c|}{$\begin{array}{r}\text { Full sample of commercial banks available in } \\
\text { Bankscope (324 banks) }\end{array}$} & \multicolumn{4}{c|}{ Our sample (207 banks) } \\
\hline Variable & Mean & Std. Dev. & Min & Max & Mean & Std. Dev. & Min & Max \\
\hline Total assets $(€$ th.) & $1,724,172$ & $3,846,473$ & 957 & $3.70 \mathrm{E}+07$ & $1,797,062$ & $3,988,865$ & 957 & $3.70 \mathrm{E}+07$ \\
\hline ROA (\%) & 0.85 & 4.64 & -46.25 & 65.61 & 0.98 & 4.23 & -44.12 & 65,61 \\
\hline Equity/ Total assets (\%) & 13.80 & 13.52 & -99.98 & 98.45 & 13.18 & 9.91 & 2.79 & 68.20 \\
\hline Deposits/ Total assets (\%) & 75.94 & 16.26 & 0 & 100 & 76.16 & 16.14 & 0 & 98.51 \\
\hline Net loans/ Total assets (\%) & 45.47 & 19.97 & 0 & 98.01 & 44.59 & 19.58 & 0 & 97.24 \\
\hline Net interest margin (\%) & 5.09 & 4.59 & -35.84 & 73.01 & 4.97 & 3.95 & -31.58 & 35.15 \\
\hline $\begin{array}{l}\text { Off balance sheet/ Total } \\
\text { assets (\%) }\end{array}$ & 16.96 & 19.32 & 0 & 100 & 17.09 & 19.48 & 0 & 99.72 \\
\hline
\end{tabular}

NB: descriptive statistics are computed on the 1995-2006 period with the restriction that there is an explicit deposit insurance scheme in the considered country. 
Table 2: Definition of the dependent and independent variables and descriptive statistics on our sample.

\begin{tabular}{|c|c|c|c|c|c|c|}
\hline Variables name & Description & Mean & Std. Dev. & Min & Max & Sources \\
\hline \multicolumn{7}{|c|}{ Dependent variables } \\
\hline SDROA & The 3-year rolling window standard deviation of the ROA (return on assets). & 1.57 & 3.19 & 0.009 & 39.63 & $\begin{array}{l}\text { Bankscope and author's } \\
\text { calculations }\end{array}$ \\
\hline SDROE & The 3-year rolling window standard deviation of the ROE (return on equity). & 9.96 & 18.34 & 0.06 & 427.64 & $\begin{array}{l}\text { Bankscope and author's } \\
\text { calculations }\end{array}$ \\
\hline Z-SCORE & $\begin{array}{l}\mathrm{Z} \text {-SCORE }=(\mathrm{ROA}+\mathrm{EQTA}) / \mathrm{SDROA}, \text { where ROA is the } 3 \text {-year rolling window average } \\
\text { return on average assets, eqta is the } 3 \text {-year rolling window average ratio of Total equity to } \\
\text { total assets; sdroa is the } 3 \text {-year rolling window standard deviation of the ROA. }\end{array}$ & 39.94 & 78.38 & -0.22 & $1,408.73$ & $\begin{array}{l}\text { Bankscope and author's } \\
\text { calculations }\end{array}$ \\
\hline \multicolumn{7}{|c|}{ Bank level variables } \\
\hline MKD & Ratio of deposits due to banks to total deposits (\%). & 28.57 & 26.47 & 0 & 100 & $\begin{array}{l}\text { Bankscope and author's } \\
\text { calculations }\end{array}$ \\
\hline EQTA & Ratio of equity to total assets (\%). & 13.18 & 9.91 & 2.79 & 68.20 & $\begin{array}{l}\text { Bankscope and author's } \\
\text { calculations }\end{array}$ \\
\hline LTA & Natural logarithm of total assets. & 13.06 & 1.67 & 6.86 & 17.43 & $\begin{array}{l}\text { Bankscope and author's } \\
\text { calculations }\end{array}$ \\
\hline STATE & $\begin{array}{l}\text { Dummy variable that takes the value of one for state owned bank that is if the share of state } \\
\text { ownership in bank total ownership is higher than } 50 \text { percent, and zero otherwise. }\end{array}$ & 0.08 & 0.28 & 0 & 1 & $\begin{array}{l}\text { Bankscope and author's } \\
\text { calculations }\end{array}$ \\
\hline NII & Ratio of net interest income to total operating income (\%). & 58.44 & 20.91 & -106.50 & 99.99 & $\begin{array}{l}\text { Bankscope and author's } \\
\text { calculations }\end{array}$ \\
\hline SAVING & $\begin{array}{l}\text { Saving bank dummy. This dummy variable takes the value of one if the bank is a state } \\
\text { saving bank on the year considered, and zero otherwise. }\end{array}$ & 0.02 & 0.14 & 0 & 1 & $\begin{array}{l}\text { Bankscope and author's } \\
\text { calculations }\end{array}$ \\
\hline
\end{tabular}


Table 2- Continues

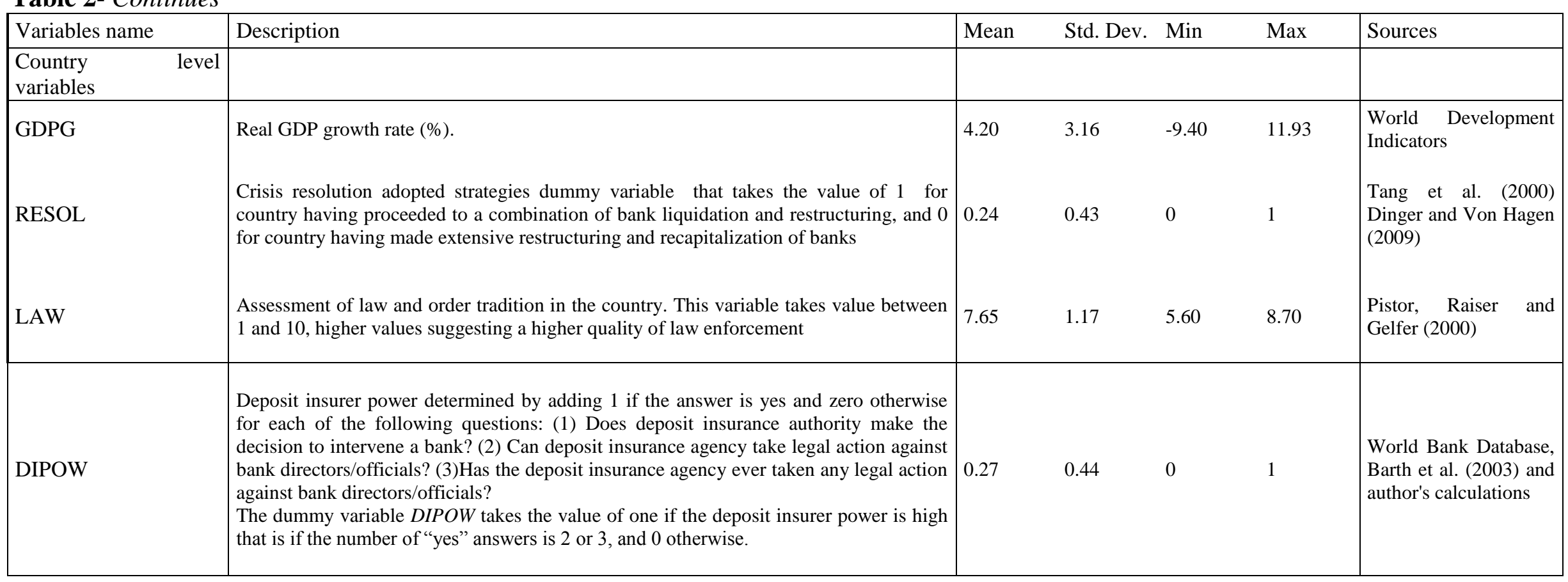


Table 3: Effectiveness of interbank deposits as market discipline factor.

Model specification:

$$
\operatorname{RISK}_{i, j, t}=\alpha_{0}+\alpha_{1} M K D_{i, j, t}+\beta_{1}^{\prime} X_{i, j, t}+\beta_{2}^{\prime} Z_{j, t}+\eta_{i}+\tau_{t}+u_{i, j, t}
$$

\begin{tabular}{|c|c|c|c|}
\hline VARIABLES & SDROE & SDROA & Z-SCORE \\
\hline \multirow[t]{2}{*}{ MKD } & $-0.068 * * *$ & $-0.008 * *$ & $0.141^{*}$ \\
\hline & $(-2.799)$ & $(-2.182)$ & $(1.712)$ \\
\hline \multirow[t]{2}{*}{ EQTA } & $-0.456^{* * *}$ & $-0.023^{*}$ & $0.693^{* *}$ \\
\hline & $(-5.484)$ & $(-1.687)$ & $(2.561)$ \\
\hline \multirow[t]{2}{*}{ LTA } & $-4.396 * * *$ & $-0.689 * * *$ & $5.236^{*}$ \\
\hline & $(-3.803)$ & $(-4.715)$ & $(1.741)$ \\
\hline \multirow[t]{2}{*}{ STATE } & $-5.849 * * *$ & -0.140 & 10.68 \\
\hline & $(-2.804)$ & $(-0.335)$ & $(1.315)$ \\
\hline \multirow[t]{2}{*}{ NII } & 0.010 & $-0.011 * *$ & -0.087 \\
\hline & $(0.336)$ & $(-2.515)$ & $(-1.099)$ \\
\hline \multirow[t]{2}{*}{ SAVING } & -1.119 & $-0.986 * * *$ & 5.194 \\
\hline & $(-0.439)$ & $(-3.374)$ & $(0.289)$ \\
\hline \multirow[t]{2}{*}{ GDPG } & $-0.508 * * *$ & $-0.166^{* * * *}$ & $1.469 * * *$ \\
\hline & $(-2.827)$ & $(-4.168)$ & $(2.703)$ \\
\hline \multirow[t]{2}{*}{ RESOL } & $-6.540 * *$ & $-1.028 * * *$ & $50.880 * * *$ \\
\hline & $(-2.008)$ & $(-4.030)$ & $(6.814)$ \\
\hline \multirow[t]{2}{*}{ LAW } & $-2.919 * * *$ & $-0.373 * * *$ & $51.600 * * *$ \\
\hline & $(-2.608)$ & $(-4.302)$ & $(21.810)$ \\
\hline \multirow[t]{2}{*}{ DIPOW } & $-8.399 * *$ & $-0.376^{*}$ & -13.520 \\
\hline & $(-2.533)$ & $(-1.867)$ & $(-1.122)$ \\
\hline \multirow[t]{2}{*}{ CONSTANT } & $111.700 * * *$ & $15.580 * * *$ & $-405.100 * * *$ \\
\hline & $(7.643)$ & $(6.991)$ & $(-8.881)$ \\
\hline OBSERVATIONS & 1060 & 1083 & 1080 \\
\hline R-SQUARED & 0.534 & 0.563 & 0.470 \\
\hline
\end{tabular}

$\overline{S D R O A}=$ standard deviation of the ROA; SDROE = standard deviation of the ROE; Z-SCORE = bank insolvency risk; $M K D$ $=$ interbank deposits to total deposits ratio; $E Q T A=$ equity to assets ratio; $N I I=$ ratio of net interest income to total operating income; $L T A=$ logarithm of total assets; $G D P G=$ growth rate of real GDP; $D I P O W=$ power of deposit insurance authority dummy variable. This dummy variable takes the value of one for countries that have a deposit insurance authority power index equals two or more, and zero otherwise; $R E S O L=$ crises resolution strategies dummy variable that takes the value of 1 for country having proceeded to a combination of bank liquidation and restructuring, and 0 for country having made extensive restructuring and recapitalization of banks; $L A W=$ rule of law. This variable takes value between 1 and 10 , higher values suggesting a higher quality of law enforcement; STATE = state owned bank dummy variable. This dummy variable takes the value of one for banks in which state ownership represents at least 50 percent of total share, and zero otherwise; SAVING = state saving bank dummy variable. This dummy variable takes the value of one if the bank is a state saving bank on the year considered, and zero otherwise. Bank and time fixed effects are included but not reported. Robust t-statistics are in parentheses. *, **, *** represent statistical significance at the $10 \%, 5 \%$, and $1 \%$ levels, respectively. 
Table 4: Influence of implicit insurance through state ownership on the effectiveness of market discipline.

Model specification:

\begin{tabular}{|c|c|c|c|}
\hline VARIABLES & SDROE & SDROA & Z-SCORE \\
\hline \multirow[t]{2}{*}{ MKD } & $-0.077 * * *$ & $-0.010 * * *$ & $0.151^{*}$ \\
\hline & $(-2.959)$ & $(-2.869)$ & (1.889) \\
\hline \multirow[t]{2}{*}{ STATE $*$ MKD } & $0.117 *$ & $0.0301 * *$ & -0.126 \\
\hline & (1.933) & $(2.032)$ & $(-0.438)$ \\
\hline \multirow[t]{2}{*}{ EQTA } & $-0.461 * * *$ & $-0.024 *$ & $0.698 * * *$ \\
\hline & $(-5.532)$ & $(-1.747)$ & $(2.590)$ \\
\hline \multirow[t]{2}{*}{ LTA } & $-4.451 * * *$ & $-0.698 * * *$ & $5.286^{*}$ \\
\hline & $(-3.852)$ & $(-4.768)$ & $(1.761)$ \\
\hline \multirow[t]{2}{*}{ STATE } & $-8.512 * * *$ & $-0.882 * *$ & 13.440 \\
\hline & $(-3.731)$ & $(-2.297)$ & $(1.586)$ \\
\hline \multirow[t]{2}{*}{ NII } & 0.010 & $-0.011 * *$ & -0.088 \\
\hline & $(0.362)$ & $(-2.511)$ & $(-1.119)$ \\
\hline \multirow[t]{2}{*}{ SAVING } & -0.608 & $-0.825 * * *$ & 4.714 \\
\hline & $(-0.245)$ & $(-2.962)$ & $(0.262)$ \\
\hline \multirow[t]{2}{*}{ GDPG } & $-0.531 * * *$ & $-0.169 * * *$ & $1.483 * * *$ \\
\hline & $(-2.944)$ & $(-4.261)$ & $(2.738)$ \\
\hline \multirow[t]{2}{*}{ RESOL } & $-6.020 *$ & $-1.194 * * *$ & $49.810 * * *$ \\
\hline & $(-1.839)$ & $(-4.388)$ & $(6.018)$ \\
\hline \multirow[t]{2}{*}{ LAW } & $-3.051 * * *$ & $-0.345 * * *$ & $50.960 * * *$ \\
\hline & $(-2.752)$ & $(-3.962)$ & (18.010) \\
\hline \multirow[t]{2}{*}{ DIPOW } & $-9.817 * * *$ & $-0.453 * *$ & -13.790 \\
\hline & $(-2.787)$ & $(-2.223)$ & $(-1.163)$ \\
\hline \multirow[t]{2}{*}{ CONSTANT } & $114.800 * * *$ & $15.760 * * *$ & $-401.300 * * *$ \\
\hline & $(7.877)$ & $(7.050)$ & $(-8.434)$ \\
\hline$\alpha_{1}+\alpha_{2}$ & 0.040 & 0.020 & 0.025 \\
\hline Risk level to reject : $\alpha_{1}+\alpha_{2}=0$ & 0.470 & 0.166 & 0.935 \\
\hline OBSERVATIONS & 1060 & 1083 & 1080 \\
\hline R-SQUARED & 0.536 & 0.569 & 0.470 \\
\hline
\end{tabular}

$\overline{S D R O A}=$ standard deviation of the ROA; SDROE = standard deviation of the ROE; Z-SCORE = bank insolvency risk; $M K D=$ interbank deposits to total deposits ratio; $E Q T A=$ equity to assets ratio; $N I I=$ ratio of net interest income to total operating income; $L T A=$ logarithm of total assets; GDPG = growth rate of real GDP; DIPOW = power of deposit insurance authority dummy variable. This dummy variable takes the value of one for countries that have a deposit insurance authority power index equals two or more, and zero otherwise; $R E S O L=$ crises resolution strategies dummy variable that takes the value of 1 for country having proceeded to a combination of bank liquidation and restructuring, and 0 for country having made extensive restructuring and recapitalization of banks; $L A W=$ rule of law. This variable takes value between 1 and 10 , higher values suggesting a higher quality of law enforcement; STATE =state owned bank dummy variable. This dummy variable takes the value of one for banks in which state ownership represents at least 50 percent of total share, and zero otherwise; SAVING = state saving bank dummy variable. This dummy variable takes the value of one if the bank is a state saving bank on the year considered, and zero otherwise. Bank and time fixed effects are included but not reported. Robust t-statistics are in parentheses. $*, * *, * * *$ represent statistical significance at the $10 \%, 5 \%$, and $1 \%$ levels, respectively. 
Table 5: Influence of the deposit insurer power on the effectiveness of market discipline.

Model specification:

\begin{tabular}{|c|c|c|c|}
\hline VARIABLES & SDROE & SDROA & Z-SCORE \\
\hline \multirow[t]{2}{*}{ MKD } & $-0.074 * * *$ & $-0.007 *$ & 0.083 \\
\hline & $(-2.844)$ & $(-1.784)$ & (1.042) \\
\hline \multirow[t]{2}{*}{ DIPOW*MKD } & 0.024 & -0.003 & 0.218 \\
\hline & $(0.486)$ & $(-0.396)$ & $(1.085)$ \\
\hline \multirow[t]{2}{*}{ EQTA } & $-0.456 * * *$ & $-0.0233 *$ & $0.686^{* *}$ \\
\hline & $(-5.504)$ & $(-1.679)$ & $(2.547)$ \\
\hline \multirow[t]{2}{*}{ LTA } & $-4.429 * * *$ & $-0.685^{* * *}$ & $4.948^{*}$ \\
\hline & $(-3.802)$ & $(-4.623)$ & (1.654) \\
\hline \multirow[t]{2}{*}{ STATE } & $-5.858 * * *$ & -0.135 & 10.560 \\
\hline & $(-2.798)$ & $(-0.326)$ & (1.325) \\
\hline \multirow[t]{2}{*}{ NII } & 0.011 & $-0.011 * *$ & -0.077 \\
\hline & $(0.379)$ & $(-2.520)$ & $(-0.986)$ \\
\hline \multirow[t]{2}{*}{ SAVING } & -0.970 & $-1.005^{* * *}$ & 6.418 \\
\hline & $(-0.378)$ & $(-3.444)$ & $(0.358)$ \\
\hline \multirow[t]{2}{*}{ GDPG } & $-0.502 * * *$ & $-0.166 * * *$ & $1.487 * * *$ \\
\hline & $(-2.815)$ & $(-4.157)$ & $(2.743)$ \\
\hline \multirow[t]{2}{*}{ RESOL } & $-6.725 * *$ & $-1.071 * * *$ & $50.720 * * *$ \\
\hline & $(-2.064)$ & $(-3.812)$ & $(6.886)$ \\
\hline \multirow[t]{2}{*}{ LAW } & $-2.759 * *$ & $-0.410 * * *$ & $53.04 * * *$ \\
\hline & $(-2.373)$ & $(-3.990)$ & $(21.20)$ \\
\hline \multirow[t]{2}{*}{ DIPOW } & $-8.907 * * *$ & -0.236 & -18.39 \\
\hline & $(-2.596)$ & $(-0.688)$ & $(-1.418)$ \\
\hline \multirow[t]{2}{*}{ CONSTANT } & $111.100 * * *$ & $15.790 * * *$ & $-410.300 * * *$ \\
\hline & $(7.654)$ & $(7.085)$ & $(-8.938)$ \\
\hline$\alpha_{1}+\alpha_{2}$ & -0.050 & -0.010 & 0.301 \\
\hline Risk level to reject : $\alpha_{1}+\alpha_{2}=0$ & 0.278 & 0.173 & 0.123 \\
\hline OBSERVATIONS & 1060 & 1083 & 1080 \\
\hline R-SQUARED & 0.535 & 0.563 & 0.471 \\
\hline
\end{tabular}

SDROA = standard deviation of the ROA; SDROE = standard deviation of the ROE; Z-SCORE = bank insolvency risk; $M K D=$ interbank deposits to total deposits ratio; $E Q T A=$ equity to assets ratio; $N I I=$ ratio of net interest income to total operating income; $L T A=$ logarithm of total assets; $G D P G=$ growth rate of real GDP; $D I P O W=$ power of deposit insurance authority dummy variable. This dummy variable takes the value of one for countries that have a deposit insurance authority power index equals two or more, and zero otherwise; $R E S O L=$ crises resolution strategies dummy variable that takes the value of 1 for country having proceeded to a combination of bank liquidation and restructuring, and 0 for country having made extensive restructuring and recapitalization of banks; $L A W=$ rule of law. This variable takes value between 1 and 10, higher values suggesting a higher quality of law enforcement; STATE = state owned bank dummy variable. This dummy variable takes the value of one for banks in which state ownership represents at least 50 percent of total share, and zero otherwise; SAVING = state saving bank dummy variable. This dummy variable takes the value of one if the bank is a state saving bank on the year considered, and zero otherwise. Bank and time fixed effects are included but not reported. Robust t-statistics are in parentheses. $*, * *, * * *$ represent statistical significance at the $10 \%, 5 \%$, and $1 \%$ levels, respectively. 


\section{Table 6: Influence of the banking crisis resolution strategy on the effectiveness of market discipline.}

Model specification:

\begin{tabular}{|c|c|c|c|}
\hline VARIABLES & SDROE & SDROA & Z-SCORE \\
\hline \multirow[t]{2}{*}{ MKD } & $-0.061 * *$ & $-0.007 *$ & $0.200 * *$ \\
\hline & $(-2.249)$ & $(-1.793)$ & $(2.001)$ \\
\hline \multirow[t]{2}{*}{ RESOL*MKD } & -0.028 & -0.001 & -0.241 \\
\hline & $(-0.583)$ & $(-0.210)$ & $(-1.433)$ \\
\hline \multirow[t]{2}{*}{ EQTA } & $-0.456 * * *$ & $-0.0234 *$ & $0.689 * *$ \\
\hline & $(-5.468)$ & $(-1.687)$ & $(2.566)$ \\
\hline \multirow[t]{2}{*}{ LTA } & $-4.406 * * *$ & $-0.690 * * *$ & $5.108 *$ \\
\hline & $(-3.817)$ & $(-4.724)$ & (1.697) \\
\hline \multirow[t]{2}{*}{ STATE } & $-5.847 * * *$ & -0.140 & 10.810 \\
\hline & $(-2.810)$ & $(-0.335)$ & (1.332) \\
\hline \multirow[t]{2}{*}{ NII } & 0.010 & $-0.011 * *$ & -0.086 \\
\hline & $(0.337)$ & $(-2.514)$ & $(-1.088)$ \\
\hline \multirow[t]{2}{*}{ SAVING } & -1.035 & $-0.983 * * *$ & 5.762 \\
\hline & $(-0.406)$ & $(-3.368)$ & $(0.321)$ \\
\hline \multirow[t]{2}{*}{ GDPG } & $-0.504 * * *$ & $-0.166 * * *$ & $1.490 * * *$ \\
\hline & $(-2.814)$ & $(-4.164)$ & $(2.738)$ \\
\hline \multirow[t]{2}{*}{ RESOL } & $-6.097 *$ & $-0.989 * * *$ & $55.580 * * *$ \\
\hline & $(-1.889)$ & $(-3.003)$ & $(6.355)$ \\
\hline \multirow[t]{2}{*}{ LAW } & $-2.934 * * *$ & $-0.376 * * *$ & $50.450 * * *$ \\
\hline & $(-2.616)$ & $(-4.279)$ & $(19.43)$ \\
\hline \multirow[t]{2}{*}{ DIPOW } & $-8.005^{* *}$ & $-0.365^{*}$ & -10.850 \\
\hline & $(-2.343)$ & $(-1.728)$ & $(-0.898)$ \\
\hline \multirow[t]{2}{*}{ CONSTANT } & $111.300 * * *$ & $15.570 * * *$ & $-400.700^{* * *}$ \\
\hline & $(7.590)$ & $(6.975)$ & $(-8.749)$ \\
\hline$\alpha_{1}+\alpha_{2}$ & $-0.089 * *$ & -0.009 & -0.041 \\
\hline Risk level to reject : $\alpha_{1}+\alpha_{2}=0$ & 0.039 & 0.130 & 0.767 \\
\hline OBSERVATIONS & 1060 & 1083 & 1080 \\
\hline R-SQUARED & 0.535 & 0.563 & 0.471 \\
\hline
\end{tabular}

SDROA = standard deviation of the ROA; SDROE = standard deviation of the ROE; Z-SCORE = bank insolvency risk; $M K D=$ interbank deposits to total deposits ratio; $E Q T A=$ equity to assets ratio; $N I I=$ ratio of net interest income to total operating income; $L T A=$ logarithm of total assets; $G D P G=$ growth rate of real GDP; $D I P O W=$ power of deposit insurance authority dummy variable. This dummy variable takes the value of one for countries that have a deposit insurance authority power index equals two or more, and zero otherwise; $R E S O L=$ crises resolution strategies dummy variable that takes the value of 1 for country having proceeded to a combination of bank liquidation and restructuring, and 0 for country having made extensive restructuring and recapitalization of banks; $L A W=$ rule of law. This variable takes value between 1 and 10 , higher values suggesting a higher quality of law enforcement; STATE = state owned bank dummy variable. This dummy variable takes the value of one for banks in which state ownership represents at least 50 percent of total share, and zero otherwise; SAVING = state saving bank dummy variable. This dummy variable takes the value of one if the bank is a state saving bank on the year considered, and zero otherwise. Bank and time fixed effects are included but not reported. Robust t-statistics are in parentheses. $*, * *, * * *$ represent statistical significance at the $10 \%, 5 \%$, and $1 \%$ levels, respectively. 